\title{
PENGARUH PENGHINDARAN PAJAK, KEPEMILIKAN INSTITUSIONAL, DAN PROFITABILITAS TERHADAP BIAYA HUTANG \\ (Studi Empiris Pada Perusahaan Manufaktur Yang Terdaftar Di BEI Periode 2011-2015)
}

\author{
Elvis Nopriyanti Sherly, Desi Fitria \\ Program Studi Akuntansi Ekonomi Universitas Muhammadiyah Bengkulu \\ elvisnopriyantisherly@gmail.com
}

\begin{abstract}
ABSTRAK
Elvis Nopriyanti Sherly, Desi Fitria; Penelitian ini bertujuan untuk mengetahui pengaruh Penghindaran Pajak, Kepemilikan Institusional, dan Profitabilitas terhadap Biaya Hutang. Sampel dalam penelitian terdiri dari 71 perusahaan manufaktur yang terdaftar di Bursa Efek Indonesia dari tahun 2011-2015 dengan metode purposive sampling.

Hasil penelitian ini menunjukkan bahwa penghindaran pajak berpengaruh negatif terhadap biaya hutang. Semakin kecil Cash Effective Tax Rate maka biaya hutang (Cost of Debt) akan semakin besar. Hasil penelitian ini juga menunjukkan kepemilikan institusional tidak berpengaruh terhadap biaya hutang. Selanjutnya, hasil penelitian profitabilitas yang diproksikan dengan Return on Assets (ROA) berpengaruh negatif terhadap biaya hutang artinya semakin tinggi profitabilitas perusahaan maka perusahaan akan memiliki dana internal yang tinggi yang dapat digunakan dalam pembiayaan sehingga penggunaan hutang semakin kecil yang menyebabkan biaya hutang juga menjadi kecil.
\end{abstract}

\begin{abstract}
Elvis Nopriyanti Sherly, Desi Fitria; The purpose of this study is to prove the effect of tax avoidance, institutional ownership, and profitability on cost of debt. The sample consisted of 71 manufactured firms in listed in Indonesian Stock Exchange from 2011-2015 by using a purposive sampling method.

The results of the study showed that the tax avoidance had negative effect on cost of debt. The meaning is getting smaller Cash Effective Tax Rate the cost of debt incurred greater. The results of this study also showed that the institutional ownership doesn't had effect on cost of debt. Furthermore, the result of Return on Assets (ROA) as proxy profitability had a negative effect on cost of debt. The meaning that the higher the profitability of the company then the company will have a high internal funds that can be used in making the use of debt financing is getting smaller which causes the cost of debt also becomes smaller.
\end{abstract}

Key Words: Tax Avoidance, Institutional Ownership, Profitability, Cost of Debt.

\section{LATAR BELAKANG}

Perusahaan dalam menjalankan usahanya membutuhkan dana untuk membiayai aktivitas perusahaan sebagai modal kerja sehingga kegiatan operasional perusahaan dapat berjalan dengan baik. Modal kerja perusahaan dapat berasal dari modal internal perusahaan dan modal eksternal. Modal internal berasal dari modal kegiatan perusahaan dalam suatu periode seperti laba perusahaan yang tidak dibagikan kepada pemegang saham. Sedangkan modal eksternal berasal dari kreditur seperti bank dan lembaga keuangan lainnya.

Hutang merupakan salah satu sumber pendanaan eksternal yang dapat membiayai aktivitas perusahaan. Penggunaan hutang membuat pemilik berharap agar manajer lebih disiplin karena manajer tentunya harus bertanggung jawab terhadap hutang yang digunakan (Brigham dan Houston, 2011). Manajer harus memikirkan pembayaran hutang yaitu berupa pokok pinjaman dan beban bunganya kepada kreditur, sedangkan disisi lainnya manajer harus memikirkan kepentingan para pemegang saham. Dengan tanggung jawab demikian, apabila hutang tersebut tidak dilunasi seperti yang diisyaratkan, maka dapat membuat perusahaan bangkrut dan membuat para manajer kehilangan pekerjaannya.

Penggunaan hutang oleh perusahaan akan menimbulkan biaya hutang (cost of debt). Biaya hutang merupakan tingkat pengembalian yang diharapkan kreditur saat melakukan pendanaan dalam suatu perusahaan (Fabozzi 2007). Menurut Brigham dan Houston (2011) salah satu alasan dipilihnya utang sebagai sumber pendanaan adalah manfaat pajak. Pembayaran bunga merupakan faktor yang mengurangi pajak (Harmono, 2011). Dalam aturan perpajakan Indonesia, besarnya beban bunga dapat dikategorikan sebagai pengurang penghasilan kena pajak (deductible expense) sehingga akan mengurangi jumlah beban pajak perusahaan. Banyak perusahaan memanfatkan aturan tersebut sebagai salah satu cara untuk melakukan manajamen pajak sehingga akan memperkecil besarnya pajak yang dibayarkan. 
Modigliani dan Miller dalam Brigham dan Houston (2011) mengembangkan teori trade-off yang menunjukkan bahwa utang bermanfaat karena bunga dapat dikurangkan dalam menghitung pajak, tetapi utang juga menimbulkan biaya yang berhubungan dengan kebangkrutan yang aktual dan potensial. Trade off theory menjelaskan bahwa perusahaan akan berhutang pada tingkat optimal dan penghematan pajak dari hutang tersebut sama dengan biaya kebangkrutan ditambah dengan biaya agensi yang timbul akibat adanya tambahan hutang. Artinya hutang dan penghematan pajak bersifat subtitusi. Selain itu, trade off theory menjelaskan bahwa penggunaan utang yang tinggi juga akan berdampak buruk bagi perusahaan, penggunaan hutang yang tinggi akan menghilangkan manfaat hutang sebagai tax shield bagi perusahaan, hal ini karena ketika penggunaan hutang terlalu tinggi maka biaya hutang yang ditimbulkan juga semakin tinggi, sehingga akan meningkatkan biaya agensi dan biaya kebangkrutan (Fadli, 2010).

Penelitian Lim (2011) mendukung teori trade-off dan menyatakan bahwa upaya untuk memperkecil pajak seperti perlindungan pajak (tax shelter) dan penghindaran pajak (tax avoidance) merupakan substitusi dari penggunaan hutang. Penghindaran pajak (tax avoidance) ini lebih memanfaatkan celah-celah dalam undang-undang perpajakan tersebut dan akan mempengaruhi penerimaan Negara dari sektor pajak (Mangonting, 1999 dalam Dewi dan Jati 2014). Perusahaan lebih menggunakan penghindaran pajak (tax avoidance) untuk meminimalkan pajak yang akan disetorkan kepada negara dibandingkan meningkatkan penggunaan hutang sehingga itu akan meningkatkan financial slack, mengurangi biaya dan risiko kebangkrutan, meningkatkan kualitas kredit karena penggunaan utang yang tidak tinggi, yang dampaknya akan mengurangi cost of debt (Lim, 2011).

Penelitian tentang hubungan antara penghindaran pajak (tax avoidance) dan biaya hutang antara lain penelitian yang dilakukan oleh Kholbadalov (2012) dan Lim (2011) yang menyatakan bahwa adanya hubungan yang negatif dan signifikan antara penghindaran pajak dan biaya hutang perusahaan. Penghindaran pajak (tax avoidance) dapat menggantikan penggunaan hutang. Hasil penelitian Kholbadalov (2012) dan Lim (2011) ini bertentangan dengan hasil penelitian yang dilakukan oleh Masri dan Martani (2012) yang menyatakan bahwa penghindaran pajak (tax avoidance) berpengaruh positif terhadap biaya hutang.

Kepemilikan institusional salah satu bentuk struktur kepemilikan yang dapat dipilih oleh perusahaan. Hasil dari penelitian Wahidahwati (2001) menunjukkan bahwa struktur kepemilikan secara teoritis mempunyai hubungan dengan hutang. Kepemilikan institusional memiliki kemampuan dalam memonitoring manajemen sehingga dapat mengurangi sikap oportunistik manajemen (Ngadiman dan Puspitasari, 2014). Kepemilikan institusional yang besar akan memperbesar pengawasan terhadap manajemen sehingga manajemen akan berusaha untuk bekerja dengan lebih baik dalam melaksanakan pengelolaan perusahaan (Juniarti, 2009). Selain itu melalui kepemilikan institusional ini juga akan mengurangi penggunaan hutang oleh manajemen sehingga akan menurunkan biaya utang yang dibebankan pada perusahaan. Adanya kontrol ini akan menyebabkan manajemen menggunakan hutang pada tingkat yang rendah untuk mengantisipasi kemungkinan terjadinya financial distress dan financial risk (Crutchley, 1999 dalam Setyawati, 2014).

Juniarti (2009), dan Yunita (2012) meneliti pengaruh kepemilikan institusional dan biaya hutang mendapatkan hasil bahwa kepemilikan institusional berpengaruh signifikan terhadap biaya hutang. Sedangkan Agustami dan Yunanda (2014) memperoleh hasil bahwa kepemilikan insitusional berpengaruh negatif dengan biaya hutang. Dengan adanya kepemilikan institusional dapat memberikan pengaruh yang berarti karena kepemilikan institusional bertindak sebagai monitoring kepada pihak manajemen (Juniarti, 2009). Semakin besarnya kepemilikan institusional ini maka akan memperbesar kontrol kepada manajemen sehingga diharapkan kinerja manajemen pun semakin baik. Hal ini berkaitan dengan biaya hutang yang akan ditanggung oleh perusahaan sebagai tingkat pengembalian yang diminta oleh kreditur

Profitabilitas juga menentukan keputusan dalam penggunaan hutang untuk pendanaan perusahaan. Perusahaan dengan tingkat profitabilitas yang tinggi umumnya menggunakan hutang dalam jumlah yang relatif sedikit karena dengan tingkat pengembalian investasi yang tinggi perusahaan dapat melakukan permodalan dengan laba ditahan saja (Purba, 2011). Penggunaan hutang yang rendah menyebabkan biaya hutang yang ditimbulkan juga menjadi rendah. Return on Assets (ROA) merupakan proksi yang digunakan untuk menilai profitabilitas perusahaan dalam penelitian ini. Semakin tinggi nilai ROA ini maka semakin baik kinerja keuangan perusahaan tersebut karena mencerminkan bagaimana assets digunakan untuk memperoleh laba perusahaan.

\section{Teori Agensi}

Jensen dan Mecling (1976) menyatakan bahwa hubungan keagenan sebagai kontrak antara satu atau beberapa orang (principal) yang memperkerjakan orang lain (agen) untuk melakukan sejumlah jasa 
dan memberikan wewenang dalam pengambilan keputusan. Pihak manajemen perusahaan merasa bahwa beban pajak perusahaan terlalu tinggi sehingga terkadang pihak manajemen merasa akan tidak terpenuhinya kebutuhan pemegang saham sehingga menyebabkan terjadinya asimetri informasi antara pemilik dengan manajemen. Selain itu masalah asimetri informasi ini juga terjadi antara manajer dengan debtholder. Penghindaran pajak yang dilakukan oleh manajemen akan menyebabkan kurangnya transparansi dari manajemen baik kepada pemegang saham maupun kepada debtholder.

Eisenhardt (1989) dalam Juniarti (2009) menyatakan bahwa teori keagenan menggunakan tiga asumsi sifat manusia, yakni (1) manusia pada umumnya mementingkan diri sendiri (self interest), (2) manusia memiliki daya pikir terbatas mengenai persepsi masa mendatang (bounded rationality), dan (3) manusia selalu menghindari resiko (risk averse). Dengan demikian dapat disimpulkan manajer sebagai agen yang menjalankan perusahaan akan bertindak untuk mementingkan dirinya sendiri, namun dalam hal membayar pajak sesuai dengan ketentuan undang-undang yang berlaku dan untuk memenuhi kepentingan para pemegang saham manajer akan melakukan berbagai tindakan, termasuk didalamnya adalah manajemen laba. Hal ini dianggap oleh manajer tidak melanggar peraturan dan dengan demikian maka manajer akan terus diberikan kepercayaan untuk mengelola perusahaan oleh para pemegang saham.

\section{Trade Off Theory}

Teori trade off ini menjelaskan hubungan keseimbangan antara keuntungan dan kerugian penggunaan hutang oleh perusahaan dimana ada pajak perusahaan yang diperhitungkan (Putera, 2006). Menurut trade of theory, perusahaan akan berutang sampai pada tingkat hutang tertentu dimana penghematan pajak (tax shields) dari tambahan hutang sama dengan biaya kesulitan keuangan. Biaya kesulitan keuangan ini antara lain terdiri dari biaya kebangrutan dan biaya keagenan yang timbul akibat dari kredibilitas perusahaan yang menurun.

Trade-off theory ini menggunakan pilihan penggunaan hutang yang optimal. Tingkat hutang yang optimal tercapai ketika penghematan pajak mencapai jumlah yang maksimal terhadap biaya kesulitan keuangan. Artinya hutang memberikan manfaat perlindungan pajak. Jadi struktur modal yang optimal terbentuk ketika manfaat perlindungan pajak dari hutang sama dengan biaya kebangkrutan yang diterima perusahaan (Brigham dan Houston, 2011). Perusahaan yang memiliki profitabilitas yang tinggi tentu akan berusaha mengurangi pajaknya dengan cara menaikkan rasio hutang perusahaan sehingga tambahan hutang yang dilakukan perusahaan akan mengurangi pajak yang akan dibayarkan oleh perusahaan kepada pemerintah.

Trade Off Theory mengemukakan bahwa hutang mempunyai dua sisi yaitu sisi positif dan sisi negatif. Sisi positif dari hutang adalah bahwa pembayaran bunga akan mengurangi pembayaran kena pajak. Penghematan pajak ini akan meningkatkan nilai pasar perusahaan. Hutang menguntungkan perusahaan karena adanya perbedaan perlakuan pajak terhadap bunga dan dividen. Pembayaran bunga diperhitungkan sebagai biaya dan mengurangi penghasilan kena pajak, sehingga jumlah pajak yang harus dibayar perusahaan berkurang. Sebaliknya, pembagian dividen kepada pemegang saham tidak mengurangi jumlah pajak perusahaan. Jadi, dari sisi pajak akan lebih menguntungkan jika perusahaan membiayai investasi dalam bentuk hutang karena adanya penghematan pajak.

\section{Penghindaran Pajak terhadap Biaya Hutang}

Trade off theory menjelaskan bahwa penghindaran pajak (tax avoidance) adalah pengganti dari penggunaan utang (Lim,2011; Kholbadalov, 2012). Artinya penghindaran pajak dapat menjadi subtitusi dari penggunaan hutang karena ketika perusahaan tidak menggunakan hutang dalam pendanaan perusahaan maka pajak perusahaan tersebut tinggi. Hal ini terjadi karena biaya hutang yang ditimbulkan dari penggunaan hutang berupa beban bunga dapat menjadi pengurang dalam laba perusahaan sehingga laba perusahaan menjadi kecil dan pajak yang dibayarkanpun juga menjadi kecil.

Perusahaan menggunakan hutang lebih banyak ketika terlibat dalam penghindaran pajak. Hal ini mempengaruhi struktur modal perusahaan, yaitu apakah melakukan pendanaan yang berasal dari modal sendiri yaitu modal saham dan laba ditahan atau dari pihak eksternal berupa utang (Graham dan Tucker, 2006). Menurut Graham dan Trucker (2006) mengatakan jika penghindaran pajak sebagai subtitusi untuk penggunaan hutang, maka dapat meningkatkan financial slack, menghindari biaya kebangkrutan, menaikan kualitas audit, resiko gagal bayar rendah, sehingga dapat mengurangi biaya hutang. Perusahaan akan memilih tingkat hutang yang berhubungan negatif dengan tingkat tax shield bukan hutang (De Angelo and Masulis, 1980). 
Penelitian Lim (2011), penelitian yang dilakukan Kholbadalov (2012) dan Simanjuntak dan Sari (2014) juga menyimpulkan bahwa penghindaran pajak mempunyai pengaruh yang negatif terhadap biaya utang. Jika perusahaan tidak menggunakan debt financing maka akan menyebabkan perusahaan menggunakan hutang yang lebih sedikit dan akan menurunkan biaya hutang perusahaan (Simanjuntak dan Sari, 2014). Hasil penelitian tersebut mengungkapkan semakin besar penghindaran pajak maka akan semakin mengurangi biaya hutang. Berdasarkan uraian tersebut maka penelitian ini akan menguji hipotesis pertama yaitu:

\section{H1 : Penghindaran pajak berpengaruh negatif terhadap biaya hutang.}

\section{Kepemilikan Institusional terhadap Biaya Hutang}

Kepemilikan institusional mempunyai peranan yang penting dalam memonitor aktivitas manajemen. Pemegang saham yang lebih besar mempunyai dorongan yang besar pula untuk mengawasi kinerja perusahaan untuk digunakan pihak-pihak yang berkepentingan (Kholbadalov, 2012). Berdasarkan sudut pandang teori keagenan, kepemilikan institusional dapat mempengaruhi hubungan antara penghindaran pajak dan biaya hutang (Kholbadalov, 2012). Selain itu kepemilikan institusional ini juga mempunyai pengaruh yang negatif pada biaya hutang sehingga mengurangi biaya agensi yang dapat mengurangi perilaku oportunistik dari manajer.

Crutchley \& Hansen dalam Juniati (2009) yang menyatakan bahwa kepemilikan oleh institusional dapat menurunkan biaya keagenan, karena dengan adanya monitoring yang efektif oleh pihak institusional menyebabkan penggunaan hutang menurun sehingga menyebabkan biaya hutang yang ditimbulkan juga menurun. Dengan demikian kepemilikan institusional dapat mengurangi agency cost of debt. Dengan hal ini dalam kepemilikan institusional dapat mengurangi biaya hutang dengan melakukan monitoring / pengawasan manajemen yang efektif. Semakin besar kepemilikan institusional maka semakin efisien fungsi monitoring terhadap manajemen dalam pemanfaatan asset perusahaan serta pencegahan pemborosan oleh manajemen (Sofyaningsih dan Hardiningsih, 2011). Berdasarkan penjelasan tersebut, maka hipotesis kedua yang dibangun dalam penelitian ini yaitu:

\section{H2 :Kepemilikan institusional berpengaruh negatif terhadap biaya hutang.}

\section{Profitabilitas terhadap Biaya Hutang}

Profitabilitas diproksikan dengan return on assets (ROA). Pengukuran kinerja dengan ROA menunjukkan cara memperoleh laba dari kemampuan modal yang diinvestasikan dalam aktiva (Maharani dan Suardana, 2014). Return on assets (ROA) merupakan indikator yang mencerminkan tingkat keberhasilan kinerja keuangan perusahaan. Semakin tingginya nilai ROA berarti menunjukkan bahwa kinerja keuangan semakin baik. Apabila nilai Return On Assets (ROA) meningkat berarti nilai profitabilitas perusahaan juga meningkat.

Profitabilitas yang tinggi menyebabkan perusahaan cenderung akan menggunakan dana internal yang tinggi dalam pembiayaan sehingga membuat perusahaan untuk memilih menggunakan dana eksternal berupa hutang yang lebih rendah (Kusuma dkk, 2013). Hal ini disebabkan karena ketika perusahaan memiliki nilai profitabilitas yang tinggi maka perusahaan akan mengalokasikan sebagian keuntungannya pada laba ditahan sebagai sumber internal untuk pembiayaan.

Berdasarkan teori keagenan manajer lebih menyukai pendanaan internal daripada menggunakan pendanaan eksternal berupa hutang karena apabila perusahaan menggunakan hutang maka akan meningkatkan risiko bagi manajer tersebut karena manajer harus memikirkan pembayaran pokok dan beban bunga dari hutang tersebut. Lebih jauh, sesuai dengan pendapat yang dikemukakan Eisenhardt (1989) dalam Juniarti (2005) bahwa sifat manajer tersebut sesuai dengan sifat manusia yaitu cenderung menghindari risiko karena dengan menggunakan hutang maka akan menimbulkan risiko bagi manajer yang pada akhirnya akan mengancam posisi manajer dalam perusahaan. Penggunaan hutang yang rendah akan menyebabkan biaya hutang (cost of debt) juga menjadi rendah. Berdasarkan uraian tersebut maka hipotesis ketiga yang akan diuji:

\section{H3 : Profitabilitas berpengaruh negatif terhadap biaya hutang.}

\section{Kerangka Penelitian}

Kerangka teoritis membantu menjelaskan hubungan antar variabel independen terhadap variabel dependen, yaitu Penghindaran Pajak, kepemilikan institusional, dan profitabilitas yang diproksikan dengan Return on Assets terhadap biaya hutang. Berdasar pada telaah literatur yang tertulis di atas, maka kerangka pemikiran yang di kembangkan dalam penelitian ini secara ringkas digambarkan sebagai 
berikut:

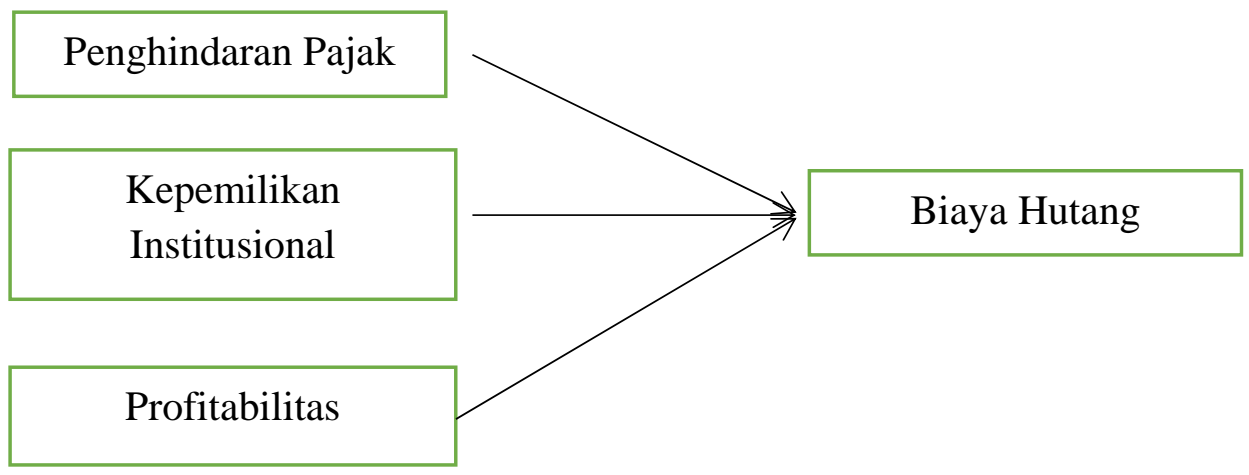

Gambar 1. Kerangka Penelitian

\section{METODE PENELITIAN}

\section{Defenisi Operasional dan Pengukuran Variabel}

Dalam penelitian ini terdapat satu variabel dependen yaitu biaya hutang, sedangkan variabel independennya yakni penghindaran pajak, kepemilikan institusional, dan profitabilitas yang diproksikan dengan return on assets (ROA).

\section{Biaya hutang}

Biaya hutang didefinisikan sebagai tingkat efektif dari pembayaran hutang lancar perusahaan (Khobaldalov, 2012). Penelitian ini menggunakan Cost of Debt (COD) sebagai proksi dari variabel biaya hutang. Penelitian ini dalam menghitung biaya hutang mengikuti rumus yang dikembangkan oleh Kholbadalov (2012) dengan cara menghitung beban bunga pada tahun tersebut dibagi dengan rata- rata hutang jangka pendek ditambah hutang jangka panjang untuk tahun yang sama. Rumusnya dapat dituliskan sebagai berikut:

\section{$C O D=\frac{(\text { Beban Bunga Tahun berjalan })}{(\text { hutang fangka pendek })+(\text { hutang Jangka panjang }) / 2}$}

\section{Penghindaran Pajak (Tax Avoidance)}

Penghindaran pajak (Tax Avoidance) dalam penelitian dapat diproksikan dengan Cash Effective Tax Rate (CETR). Cash Effective Tax Rate (CETR) adalah kas yang dikeluarkan untuk biaya pajak dibagi dengan laba sebelum pajak. Penggunaan CETR dalam penelitian ini diharapkan mampu menggambarkan adanya aktivitas penghindaran pajak.

Semakin tinggi tingkat presentase CETR yaitu mendekati tarif pajak badan sebesar 25\% mengindikasikan semakin rendah tingkat penghindaran pajak perusahaan, sebaliknya semakin rendah tingkat presentase CETR mengindikasikan semakin tinggi tingkat penghindaran pajak perusahaan. Rumus yang digunakan untuk menghitung Cash Effektif Tax Rate (CETR) mengacu pada rumus yang digunakan oleh Indarti (2015) yaitu:

$$
\text { CZTR }=\frac{\text { Beban Paịak KInd }}{\text { Laba Sebelum Pạak }}
$$

\section{Kepemilikan Institusional}

Kepemilikan institusional merupakan kepemilikan saham perusahaan yang dimiliki oleh investor institusional seperti lembaga keuangan, asuransi, pemerintah, bank dan kepemilikan institusi lainnya (Ngadiman dan Puspitasari, 2014). Kepemilikan Institusional dapat diukur menggunakan rumus dari Kholbadalov (2012) yang mengikuti rumus yang dikemukakan oleh Desai dan Dharmapala (2006) yaitu 
dengan menghitung persentase dari modal saham perusahaan yang dimiliki oleh investor institusional. Rumus yang digunakan untuk mengukur kepemilikan institusional yaitu:

Kepemilikan Institusional $=\frac{\text { Jumlah Saham Institus1 }}{\text { Jumlah Saham Beredar }} \times 100 \%$

\section{Profitabilitas}

Profitabilitas dalam penelitian ini diproksikan dengan Return on Assets. Return On Asset (ROA) merupakan salah satu indikator untuk melihat kemampuan perusahaan untuk memperoleh laba dengan menggunakan aktiva sebaik-baiknya. Rasio ini memberikan ukuran yang lebih baik atas profitabilitas perusahaan karena menunjukkan efektifitas manajemen dalam menggunakan asset untuk memperoleh pendapatan (Rudianto, 2013). Semakin besar ROA maka semakin efektif penggunaan aktiva perusahaan untuk memperoleh laba (Sudana, 2011). ROA dapat dirumuskan sebagai berikut:

\section{ROA $=\frac{\text { Labu Bursll }}{\text { Total Aooot }}$}

\section{Uji Asumsi Klasik}

Uji Normalitas

Uji normalitas data dilakukan dengan maksud untuk menguji apakah dalam model regresi, kedua variabel yakni variabel dependen dan independen memiliki distribusi normal atau tidak (Ghozali, 2013). Distribusi normal merupakan distribusi dari variabel random yang kontinyu dan merupakan distribusi yang simetris. Sebuah variabel mungkin mempunyai karakteristik yang tidak diinginkan seperti data yang tidak normal yang mengurangi ketepatan pengujian hipotesis atau bisa signifikan. Penelitian ini menggunakan Uji Statistic Jarque-Bera (JB-Test) pada aplikasi eviews 7.0 dengan melihat nilai probabilitas dari Jarque-Bera dengan nilai probabilitas 0,05. Data yang memiliki distribusi normal jika nilai probabilitas Jarque-Bera lebih besat dari tingkat signifikansinya ( $p$-value > 5\%).

\section{Uji Autokorelasi}

Uji autokorelasi dilakukan dengan tujuan untuk menguji apakah model regresi terdapat korelasi antara kesalahan penganggu pada periode et dengan kesalahan pada periode sebelumnya et-1 (Nugroho, 2005). Apabila ini terjadi maka dinamakan masalah autokorelasi.

Pengujian autokorelasi dilakukan dengan menggunakan uji Durbin-Watson (Uji D-W) dengan melihat nilai $d$ atau koefisien Durbin-Watson (DW). Jika terjadi korelasi, maka dikatakan pada model tersebut terdapat masalah autokorelasi baik itu autokorelasi positif atau negatif. Masalah autokorelasi ini muncul dikarenakan observasi yang berurutan sepanjang waktu berkaitan satu dengan yang lainnya. Pengambilan keputusan ada atau tidaknya autokorelasi pada suatu model diperlihatkan pada Tabel berikut:

Tabel 1. Kriteria Autokorelasi Durbin-Watson

\begin{tabular}{|l|l|l|}
\hline \multicolumn{1}{|c|}{ Hipotesis Nol } & \multicolumn{1}{c|}{ Keputusan } & \multicolumn{1}{c|}{ Jika } \\
\hline Tidak ada autokorelasi positif & Tolak & $0<\mathrm{d}<\mathrm{dl}$ \\
\hline Tidak ada autokorelasi positif & Tidak ada keputusan & $\mathrm{dl} \leq \mathrm{d} \leq \mathrm{du}$ \\
\hline Tidak ada autokorelasi negatif & Tolak & $4-\mathrm{dl} \leq \mathrm{d} \leq 4$ \\
\hline Tidak ada autokorelasi negatif & Tidak ada keputusan & $4-\mathrm{du} \leq \mathrm{d} \leq 4-\mathrm{dl}$ \\
\hline Tidak ada autokorelasi positif atau negatif & Tidak ditolak & $\mathrm{du}<\mathrm{d}<4-\mathrm{du}$ \\
\hline
\end{tabular}

Sumber: (Ghozali, 2013)

\section{Uji Multikolineritas}

Uji multikolinieritas dilakukan dengan tujuan untuk menguji apakah model regresi ditemukan adanya korelasi di antara variabel independen. Model dikatakan baik jika tidak terjadi korelasi di antara variabel independen. Jika variabel independen saling berkorelasi, maka variabel-variabel ini ridak ortogonal (Ghozali, 2011). Masalah multikolinieritas dapat dilihat dari koefisien korelasi masing-masing variabel independen. Jika koefisien korelasi di antara masing-masing variabel independen lebih besar dari 0,8 maka terjadi multikolinieritas Ajija dkk (2011) dalam Ramadhani (2016). 


\section{Uji Heteroskesdastisitas}

Uji heteroskesedastisitas digunakan untuk menguji terjadinya perbedaan variance residual suatu periode pengamatan ke periode pengamatan yang lain. Dalam penelitian ini untuk mendeteksi terjadinya heterokedastisitas dilakukan uji Bruesh- Pagan-Godfrey dengan menggunakan Software Eviews 7.0. Hasil yang diperhatikan dari uji ini adalah nilai $\mathrm{F}$ dan $O b s^{*} R$-squared. Jika nilai $p$-value dari $O b s^{*} R$-squared lebih besar dari 5\%, maka dapat disimpulkan bahwa model regresi tidak terjadi heterokedastisitas.

\section{Teknik Analisis Data}

Teknik analisis data dalam penelitian ini menggunakan teknik analisis regresi berganda. Analisis regresi berganda adalah alat analisis peramalan nilai pengaruh dari dua variabel bebas atau lebih terhadap variabel terikat untuk membuktikan ada atau tidaknya hubungan fungsi atau kausal antara dua variabel bebas atau lebih dengan satu variabel terikat (Riduwan dan Sunarto, 2011). Penelitian ini dihitung dengan menggunakan model regresi linear berganda sebagai berikut:

\section{CODit $=\beta 1 \mathrm{i}+\beta 2 \mathrm{iCETR}+\beta 3 \mathrm{iInsti}, \mathrm{t}+\beta 4 \mathrm{iROAi}, \mathrm{t}+\boldsymbol{\beta 5 i A g e i , t}+\beta 6 \mathrm{iCFOi}, \mathrm{t}+\beta 7 \mathrm{iSizei}, \mathrm{t}+\varepsilon i t$}

Dimana:

CODit $\quad=$ Cost of Debt (Biaya hutang)
CETRi,t = Cash Effektif Tax Rate (Penghindaran Pajak)
$\begin{array}{ll}\text { Insti,t } & =\text { Kepemilikan Institusional } \\ \text { ROAi,t } & =\text { Return } \text { on Asset } \\ \text { Agei,t } & =\text { Umur perusahaan } \\ \text { CFOi,t } & =\text { Arus kas Operasi } \\ \text { Sizei,t } & =\text { Ukuran perusahaan } \\ \text { Ei,t } & =\text { Error Term }\end{array}$

\section{HASIL PENELITIAN DAN PEMBAHASAN Populasi dan Sampel Penelitian}

Populasi dalam penelitian ini adalah seluruh perusahaan manufaktur yang terdaftar di Bursa Efek Indonesia (BEI) dari tahun 2011 sampai tahun 2015. Sampel yang digunakan dalam penelitian ini yaitu perusahaan manufaktur yang terdaftar di BEI dengan periode pengamatan ini dari tahun 2011-2015 yang memenuhi kriteria. Teknik pengambilan sampel dalam penelitian ini menggunakan metode purposive sampling.

Berdasarkan kriteria yang telah ditetapkan maka jumlah sampel dalam penelitian ini berjumlah 71 perusahaan dengan jumlah observasi sebanyak 355 observasi.

\section{Hasil Pengujian Asumsi Klasik Uji Normalitas Data}

Tabel 2. Hasil Uji Normalitas

\begin{tabular}{|c|c|c|c|}
\hline Model Persamaan & Jarque- Bera & Probability & Keterangan \\
\hline 1 & 1199914,0 & 0,000000 & Tidak Normal \\
\hline
\end{tabular}

Sumber : data sekunder diolah, 2016

Berdasarkan Tabel 2 diatas maka dapat dilihat nilai probabilitas Jarque-Bera 0,000000 lebih kecil dari nilai probabilitas $0,05(0,000000<0,05)$ yang menunjukkan bahwa data tidak terdistribusi normal, maka dalam penelitian ini selanjutnya dilakukan upaya untuk melakukan penormalan data dari seluruh variabel dengan membuang data ekstrim yang diindikasikan dengan outlier dengan bantuan software eviews 7.0 dari keseluruhan data observasi. Setelah membuang data outlier, maka data yang tersisa menjadi 204 observasi. Selanjutnya dilakukan uji normalitas kembali dengan menggunakan data yang berjumlah 204 observasi. Hasil pengujian normalitas data selanjutnya disajikan pada Tabel berikut:

Tabel 3. Hasil Uji Normalitas Data (setelah membuang outlier)

\begin{tabular}{|c|c|c|c|}
\hline Model Persamaan & Jarque- Bera & Probability & Keterangan \\
\hline 1 & 5,934305 & 0,051450 & Normal \\
\hline
\end{tabular}

Sumber : data sekunder diolah, 2016

Berdasarkan Tabel 3. diatas dapat dilihat bahwa data telah terdistribusi normal yang dilihat dari nilai Jarque-Bera sebesar 5,934305 dan nilai probabilitasnya 0,051450 yang lebih besar dari tingkat 
signifikansi 0,05. Nilai probabilitas yang lebih dari besar dari tingkat signifikansi menunjukkan bahwa model persamaan tersebut dinyatakan normal.

\section{Uji Multikolineritas}

Tabel 4. Hasil Uji Multikolineritas

\begin{tabular}{|c|c|c|c|c|}
\hline & COD & CETR & INST & ROA \\
\hline COD & 1 & -0.09655 & -0.02531 & -0.42302 \\
\hline CETR & -0.09655 & 1 & -0.01918 & -0.08806 \\
\hline INST & -0.02531 & -0.01918 & 1 & 0.01480 \\
\hline ROA & -0.42302 & -0.08806 & 0.01480 & 1 \\
\hline
\end{tabular}

Sumber: data sekunder diolah, 2016

Berdasarkan Tabel 4. diatas dapat dilihat bahwa seluruh variabel independen dalam penelitian ini memiliki nilai korelasi dibawah 0,8 sehingga dapat disimpulkan bahwa model persamaan ini terbebas dari masalah multikolineritas.

\section{Uji Autokorelasi}

Uji autokorelasi yang digunakan dalam penelitian ini adalah uji Durbin-Watson (uji D-W) dengan melihat nilai $d$ atau nilai koefisien Durbin Watson berdasarkan kriteria yang telah ditentukan. Hasil pengujian autokorelasi dapat dilihat di tabel 5. dibawah ini

Tabel 5. Hasil Uji Autokorelasi

\begin{tabular}{|c|c|c|c|c|c|c|c|}
\hline $\mathbf{k}$ & $\mathbf{N}$ & $\mathbf{D l}$ & $\mathbf{D u}$ & $\mathbf{D w}$ & $\mathbf{4 - d u}$ & Kriteria & Keterangan \\
\hline 3 & 204 & 1,7382 & 1,7990 & 1,149 & 2,201 & $0<\mathrm{d}<\mathrm{dl}$ & $\begin{array}{c}\text { Terkena Autokorelasi } \\
\text { Positif }\end{array}$ \\
\hline
\end{tabular}

Sumber: data sekunder diolah, 2016

Berdasarkan Tabel diatas, menunjukkan nilai Durbin-Watson (DW) sebesar 1,149 dengan jumlah variabel independen (k) 3, jumlah observasi (n) sebanyak 204 dan dengan $\alpha=5 \%$. Nilai Durbin Watson Lower (dl) sebesar 1,7328 dan nilai Durbin Watson Upper (du) sebesar 1,7990. Nilai Durbin Watson (dw) sebesar 1,149 dari hasil pengujian menunjukkan bahwa nilai $\mathrm{dw}$ tersebut tidak memenuhi kriteria $\mathrm{du}<\mathrm{d}<4$-du, nilai $\mathrm{dw}$ lebih kecil dari nilai $\mathrm{dl}(1,149<1,7328)$ yang mengindikasikan bahwa persamaan tersebut terkena masalah autokorelasi positif. Oleh karena itu masalah autokorelasi ini harus diobati. Masalah autokorelasi dalam penelitian ini diobati dengan metode Cochrane-Orcutt (C-D). Pemilihan metode Cochrane-Orcutt (C-D) dikarenakan nilai $\rho$ tidak diketahui. Metode ini menggunakan nilai estimasi residual $e_{t}$ untuk menghitung nilai $\rho$. Hasil uji autokorelasi setelah dilakukan pengobatan masalah autokorelasi dengan menggunakan metode Cochrane-Orcutt (C-D) disajikan dalam Tabel 6. berikut

Tabel 6. Hasil Uji Autokorelasi setelah diobati

\begin{tabular}{|c|c|c|c|l|c|c|c|}
\hline $\mathbf{k}$ & $\mathbf{N}$ & $\mathbf{D l}$ & $\mathbf{D u}$ & $\mathbf{D w}$ & 4-du & Kriteria & Keterangan \\
\hline 3 & 203 & 1,7382 & 1,7990 & 1,916 & 2,201 & $\mathrm{dl}<\mathrm{d}<4-\mathrm{du}$ & $\begin{array}{c}\text { Bebas } \\
\text { Autokorelasi }\end{array}$ \\
\hline
\end{tabular}

\section{Sumber: data sekunder diolah, 2016}

Tabel 6. di atas menunjukkan nilai Durbin-Watson (dw) sebesar 1,916. Nilai tersebut bila dibandingkan dengan kriteria terjadinya masalah autokorelasi maka nilai tersebut terletak diantara 1,7382 dan 2,201 ( $\mathrm{dl}<\mathrm{d}<4$-du). Dengan demikian maka dapat disimpulkan bahwa model persamaan tersebut telah terbebas dari masalah autokorelasi.

\section{Uji Heterokesdastisitas}

Penelitian ini menggunakan uji Gletser untuk menguji heterokesdastisitas yang dilakukan dengan meregresikan variabel-variabel independen terhadap nilai absolute residualnya (Winarno, 2015). Hasil uji heteroskedastisitas penelitian ini disajikan pada Tabel 7. Berikut:

Tabel 7. Hasil Uji Heterokesdatisitas

\begin{tabular}{|l|c|c|c|c|}
\hline \multicolumn{1}{|c|}{ Variabel } & Koefisien & T & Probability & Keterangan \\
\hline CETR1 & 0,000 & $-0,141$ & 0,888 & Bebas \\
\hline INST1 & $-0,005$ & $-0,544$ & 0,587 & Bebas \\
\hline R0A1 & 0,008 & 0,446 & 0,656 & Bebas \\
\hline
\end{tabular}

Sumber: data sekunder diolah, 2016 


\section{Pengujian Hipotesis}

Penelitian ini bertujuan untuk menjelaskan pengaruh penghindaran pajak, kepemilikan institusional, dan profitabilitas yang diproksikan dengan return on asset (ROA). Hipotesis penelitian ini terdiri dari tiga hipotesis. Dalam pengujian setiap hipotesis akan dilakukan secara bersama-sama pada table 8. sebagai berikut:

Tabel 8. Hasil Pengujian Hipotesis

\begin{tabular}{|l|c|c|r|r|c|}
\hline Variabel & $\begin{array}{c}\text { Prediksi } \\
\text { Arah }\end{array}$ & Nilai koefisien & \multicolumn{1}{c|}{ T } & Prob & Kesimpulan \\
\hline C & $\mathrm{B}$ & 0,048 & 1,591 & 0,113 & \\
\hline CETR & $(-)$ & $-0,010$ & $-2,040$ & 0,043 & Diterima \\
\hline INST & $(-)$ & 0,005 & 0,309 & 0,758 & Ditolak \\
\hline ROA & -- & $-0,152$ & -4.978 & 0,000 & Diterima \\
\hline R-squared & & \multicolumn{5}{|c|}{0,149} \\
\hline Adjusted R-squared & & \multicolumn{5}{|c|}{0,122} \\
\hline F & & 5,546 \\
\hline Sig. & & \multicolumn{5}{|c|}{0,000000} \\
\hline
\end{tabular}

Sumber: data sekunder diolah,2016

\section{Pengaruh Penghindaran Pajak terhadap Biaya Hutang}

Berdasarkan hasil pengujian hipotesis pertama menunjukkan bahwa penghindaran pajak (tax avoidance) berpengaruh negatif terhadap biaya hutang. Hasil penelitian ini mendukung teori trade-off yang dikemukakan oleh Modigliani dan Miller dalam Brigham (1999) yang berpendapat bahwa bila ada pajak penghasilan maka penggunaan hutang akan meningkatkan nilai perusahaan karena biaya bunga hutang adalah biaya yang mengurangi pembayaran pajak (tax deductable expense). Teori trade off ini menjelaskan bahwa perusahaan yang membayar pajak tinggi sebaiknya lebih banyak menggunakan hutang dibandingkan dengan perusahaan yang membayar pajak rendah. Namun demikian penggunaan hutang yang terlalu tinggi akan menghadapi bahaya kebangkrutan dan biaya keagenan yang tinggi. Penelitian ini juga membuktikan bahwa penghindaran pajak mampu mensubtitusi hutang yang berarti perusahaan menggunakan hutang yang lebih sedikit ketika mereka terlibat dalam penghindaran pajak. Dengan demikian, dapat disimpulkan bahwa hutang adalah sebagai insentif pajak yang dapat meringankan pembayaran pajak perusahaan.

Hasil penelitian ini konsisten dengan penelitian yang dilakukan oleh Kholbadalov (2012), Lim (2011) menunjukkan bahwa penghindaran pajak berpengaruh negatif terhadap biaya utang. Mereka menyatakan bahwa penghindaran pajak dan hutang bersifat subtitusi yang berarti perusahaan menggunakan hutang yang lebih sedikit ketika mereka terlibat dalam penghindaran pajak karena dengan menggunakan hutang yang sedikit akan membuat biaya hutang yang ditimbulkan akibat dari penggunaan hutang tersebut juga menjadi kecil. Namun, hasil penelitian ini tidak konsisten dengan penelitian yang dilakukan oleh Masri (2010) dan Rahmawati (2015) dengan hasil penelitian yang menunjukkan bahwa penghindaran pajak berpengaruh positif terhadap biaya hutang artinya penghindaran pajak menyebabkan biaya hutang yang semakin besar karena kreditur memandang perilaku penghindaran pajak sebagai perilaku yang mengandung risiko.

\section{Pengaruh Kepemilikan Institusional terhadap Biaya Hutang}

Hasil pengujian hipotesis kedua, diperoleh hasil bahwa kepemilikan institusional berpengaruh positif terhadap biaya utang dan tidak signifikan. Hasil ini mengindikasikan bahwa semakin tinggi tingkat kepemilikan institusional maka tidak memberikan pengaruh terhadap biaya hutang yang ditimbulkan dari penggunaan hutang oleh perusahaan. Hasil penelitian ini menolak teori agensi yang dikemukakan oleh Jensen dan Mecling (1976). Menurut teori agensi tersebut kepemilikan institusional memiliki kemampuan untuk memonitoring pihak manajemen secara efektif yaitu ditunjukkan dengan besarnya saham yang dimiliki oleh investor institusional sehingga mendorong manajemen untuk lebih memfokuskan perhatiannya pada kinerja perusahaan, sehingga mengurangi perilaku opportunistic atau perilaku mementingkan diri sendiri (Juniarti, 2009).

Tindakan pengawasan ini juga dapat mengurangi agency cost karena memungkinkan perusahaan menggunakan tingkat hutang yang rendah (Indahningrum dan Handayani, 2009). Penggunaan hutang yang rendah menyebabkan biaya hutang yang ditimbulkan juga rendah. Pemegang saham institusional sebagai pemegang saham terbesar lebih menginginkan pembiayaan perusahaan dengan hutang karena 
tidak mengurangi hak mereka (Yunita, 2012). Artinya kepemilikan institusional tidak mampu menjadi mekanisme mekanisme monitoring terhadap manajer perusahaan sehingga kepemilikan institusional belum mampu menyelesaikan persoalan keagenan yang timbul antara manajer dan pemilik perusahaan.

Hasil penelitian ini tidak konsisten dengan penelitian yang dilakukan oleh Kholbadalov (2012), Lim (2011), Agustami dan Yunanda (2013), dan Juniarti (2009) yang menunjukkan bahwa kepemilikan institusional berpengaruh negatif dan signifikan terhadap biaya utang. Artinya semakin besar kepemilikan institusional maka akan semakin kecil biaya utang yang dibebankan kepada perusahaan. Hasil penelitian ini membuktikan bahwa kepemilikan institusional tidak mampu mengawasi manajemen sehingga belum mampu mengurangi perilaku oportunistik manajemen. Selain itu, kemungkinan pihak institusional tidak melakukan tindakan pengawasan, hal ini dikarenakan tindakan pengawasan ini membutuhkan biaya yang cukup tinggi (Aripin, 2015).

Kepemilikan institusional memiliki wewenang yang lebih besar bila dibandingkan dengan pemegang saham kelompok lain untuk cenderung memilih proyek yang lebih berisiko dengan harapan akan memperoleh keuntungan yang tinggi. Pemegang saham dapat maka memilih pembiayaan proyek tersebut melalui hutang. Melalui kebijakan ini investor dapat mengalihkan penangguhan risiko kepada pihak kreditor apabila proyek gagal. Namun, apabila proyek berhasil maka investor akan mendapatkan hasil sisa proyek karena kreditor hanya akan dibayar sebesar jumlah tertentu yaitu sebesar bunga.

\section{Pengaruh Profitabilitas terhadap Biaya Hutang}

Berdasarkan hasil pengujian hipotesis ketiga diperoleh hasil bahwa profitabilitas yang diproksikan dengan return on assets (ROA) berpengaruh negatif terhadap biaya utang. Menurut Mahmuh (2004) dalam Trisono (2008) profitabilitas merupakan salah satu faktor yang mempengaruhi kebijakan hutang karena perusahaan dengan tingkat pengembalian yang tinggi atas investasinya akan menggunakan hutang yang relatif kecil. Penggunaan hutang yang kecil dalam pendanaan ini akan membuat biaya hutang yang ditimbulkan juga menjadi kecil.

Profitabilitas yang tinggi menyebabkan perusahaan lebih memilih menggunakan modal sendiri (dana internal) dibanding dengan penggunaan hutang karena nilai laba yang tinggi (Kusuma, 2013). Penggunaan dana internal disebabkan ketika profitabilitas perusahaan tinggi perusahaan mengalokasikan sebagian keuntungannya pada laba ditahan untuk tujuan investasi. Selain itu, laba yang ditahan ini dapat digunakan perusahaan sebagai sumber internal untuk pembiayaan. Dengan tingginya pendanaan internal yang dimilki perusahaan membuat perusahaan menggunakan dana eksternal yang rendah atau bahkan tidak menggunakan pendanaan eksternal sama sekali berupa hutang.

Penggunaan hutang yang rendah oleh perusahaan menyebabkan biaya hutang yang ditimbulkan dari penggunaan hutang tersebut juga rendah. Namun perusahaan akan menggunakan hutang yang tinggi ketika perusahaan memperoleh laba yang rendah sebagai mekanisme transfer kekayaan antara kreditur dan principal (Indahningrum dan Handayani, 2009). Laba yang tinggi membuat manajer lebih suka menggunakan dana internal dalam pembiayaan hal ini karena manajer cenderung lebih menyukai menghindari risiko dan penggunaan hutang ini akan menambah risiko yang mengancam posisi manajer tersebut.

Hasil penelitian ini menunjukkan hasil yang konsisten dengan penelitian Damayanti dan Hartini (2013), dan Indahningrum dan Handayani (2009) yang menunjukkan bahwa profitabilitas yang diukur dengan Return on Assets (ROA) berpengaruh negatif terhadap kebijakan hutang. Perusahaan dengan tingkat profitabilitas yang tinggi maka tingkat hutangnya rendah, dikarenakan perusahaan yang profitabilitasnya tinggi memiliki sumber dana internal yang berlimpah dan umumnya perusahaan lebih mendahulukan menggunakan dana internal setelah itu baru menggunakan dana eksternal dalam pembiayaan. Perusahaan dengan dana internal yang berlimpah secara otomatis memiliki laba ditahan yang besar. Penggunaan hutang yang rendah dalam pembiayaan menyebabkan biaya hutang yang ditimbulkan pun juga menjadi rendah.

\section{KESIMPULAN}

Pada dasarnya tujuan penelitian ini menguji secara empiris mengenai pengaruh penghindaran pajak, kepemilikan institusional, dan profitabilitas yang diproksikan dengan return on assets (ROA) terhadap biaya hutang. Berdasarkan hasil yang diperoleh dari pengolahan dan analisis data dengan bantuan alat eviews 7.0, maka dapat diambil kesimpulan sebagai berikut:

1. Penghindaran pajak terbukti berpengaruh negatif terhadap biaya hutang. Artinya semakin besar nilai Cash Effective Tax Rate (CETR) maka menunjukkan semakin rendah peghindaran pajak yang dilakukan perusahaan dan biaya hutang yang ditimbulkan juga semakin kecil. 
2. Kepemilikan institusional tidak berpengaruh terhadap biaya hutang. Artinya kepemilikan institusional tidak bisa menjadi mekanisme monitoring dalam menyelesaikan persoalan keagenan dan kepemilikan institusional merupakan insentif non pajak.

3. Profitabilitas yang diproksikan dengan Return on Assets (ROA) terbukti berpengaruh negatif terhadap biaya hutang. Hal ini membuktikan bahwa semakin tinggi return on assets (ROA), maka semakin rendah biaya utang.

\section{DAFTAR PUSTAKA}

Agustami, Silvana., Yunanda,Anggun Cahyani. (2014). Pengaruh Kepemilikan Institusional dan Pengungkapan Sukarela terhadap Biaya Hutang. Skripsi. Bandung: Universitas Pendidikan Indonesia.

Aripin, Bustanul. (2015). Pengaruh Kepemilikan Keluarga, Kepemilikan Institusional dan Kepemilikan Manajerial terhadap Biaya Hutang. Skripsi. Jakarta: Universitas Islam Negeri Syarif Hidayatullah Jakarta.

Brigham, Eugene F., dan Houston, Joel F. (2011). Manajemen Keuangan Buku Dua Edisi Kedelapan. Jakarta: Erlangga.

Damayanti, Dinar., dan Hartini, Titin (2013). Pengaruh Profitabilitas, Likuiditas, Pertumbuhan Penjualan dan Ukuran Perusahaan terhadap Kebijakan Hutang pada Perusahaan Sektor Consumer Goods di BEI Periode 2008-2012. STIE MDP.

De Angelo, Harry., \& Masulis, Ronald W. (1980). Optimal Capital Structure Under Corporate and Personal Taxation. Journal of Financial Economics. 8;3-29.

Dewi, Ni Nyoman Kristiana., dan Jati, I Ketut. (2014). Pengaruh karakter Eksekutif, Karakteristik Perusahaan, dan Dimensi Tata Kelola Perusahaan yang Baik pada Tax Avoidance di Bursa Efek Indonesia. E-Jurnal akuntansi Universitas Udayana 6.2;249-260.

Fabozzi, F.J. (2007). Bond markets, analysis, and strategies (ed.8). New Jearsey: Prentice Hall.

Ghozali, Imam. (2013). Aplikasi Analisis Multivariate dengan Program IBM SPSS21. Semarang: Universitas Diponogoro.

Graham,J.R., Tucker,A. (2006). Tax Shelter and Corporate Debt Policy. Journal of Financial Economics. 81,563-594.

Harmono. (2011). Manajemen Keuangan Berbasis Balanced Scorcard Pendekatan Teori, Kasus, dan Riset Bisnis. Jakarta: Bumi Aksara.

Ikatan Akuntan Indonesia. (2014). PSAK no.26. Biaya Pinjaman. Jakarta: Graha Akuntan.

Indahningrum, Rizka Putri., Handayani, Ratih. (2009). Analisis Pengaruh Struktur Kepemilikan, Deviden, Struktur Aset dan Profitabilitas terhadap Kebijakan Hutang Perusahaan. Jurnal Akuntansi dan Bisnis Vol.11. No.3, Desember 2009,HIm 187-209.

Januarti, Indira. (2004). Pendekatan dan Kritik Teori Akuntansi Positif. Jurnal Akuntansi dan Auditing. Volume $01 /$ no.01.

Jensen, Michael C. dab W.H. Meckling.(1976). Theory of the Firm: managerial Behavior, Agency Cost and Ownership Structure. Journal of Financial Economics. 3. Hal.305-360.

Juniarti (2009). Pengaruh Good Corporate Governance, Voluntary Disclosure terhadap Biaya Hutang (Cost of Debt). Jurnal Akuntansi dan Keuangan, Vol 11, No.2;88-100.

Kholbadalov, Utkir. (2012). The Relationship of Corporate Tax advoidance, Cost of Debt and Institusional Ownership: Evidence from Malaysia. Atlantic Review of Economics. 2st Volume. 2012.

Kusuma, Ginanjar Ishak., Suhandak., Arifin, Zainul. (2013). Analisis Pengaruh Profitabilitas (Profitability) dan Tingkat Pertumbuhan (Growth) terhadap Struktur Modal dan Nilai Perusahaan. Universitas Brawijaya Malang.

Lim, Youngdeok. (2011). Tax Avoidance, Cost Of Debt and Shareholder Activism: Evidence from Korea. Journal of Banking and Finance, 35; 456-470.

Maharani, I Gusti Ayu Cahaya., dan Suardana, Ketut Alit. (2014). Pengaruh Corporate Governance, Profitabilitas, dan Karakteristik Eksekutif pada Tax Avoidance Perusahaan Manufaktur. E-Jurnal Akuntansi Universitas Udayana 9.2; 525-539.

Masri, Indah., dan Martani, Dwi. (2012). Pengaruh Tax Avoidance terhadap Cost of Debt. Jurnal Simposium Nasional Akuntansi XV, Banjarmasin.

Ngadiman., dan Puspitasari, C. (2014). Pengaruh Leverage, Kepemilikan Institusional, dan Ukuran Perusahaan terhadap Penghindaran Pajak (Tax avoidance) pada Perusahaan Sektor Manufaktur yang Terdaftar di Bursa Efek Indonesia 2010-2012. Jurnal akuntansi. Volume XVIII, No.03;408421. 
Nugroho, Bhuono Agung. (2005). Strategi Jitu MEmilih Metode Statistik Penelitian dengan SPSS. Yogyakarta: Andi Offset.

Purba, Lenra JR. (2011). Analisis Pengaruh Kepemilikan Manajerial, Kebijakan Dividen, Ukuran Perusahaan, Profitabilitas terhadap Kebijakan Hutang (studi kasus pada perusahaan non keuangan yang terdaftar di bursa efek Indonesia tahun 2006-2009). Skripsi. Universitas Diponegoro Semarang.

Putera, Bayu Septadona. (2006). Analisis Pengaruh Struktur Kepemilikan, Rasio Pertumbuhan dan Return on Asset terhadap Kebijakan Pendanaan. Tesis. Yogyakarta: Universitas Diponegoro.

Rahmawati. (2015). Pengaruh Penghindaran Pajak dan Good Corporate Governance terhadap Biaya Utang (Studi Empiris Perusahaan Manufaktur yang Terdaftar di BEI Tahun 2009-2013). Artikel. Universitas Negeri Padang.

Setyawati, Prihandini Ayu. (2014). Analisis Pengaruh Struktur Kepemilikan, Deviden, Struktur Aset dan Profitabilitas terhadap Kebijakan Hutang Perusahaan. Skripsi. Semarang: Universitas Diponegoro Semarang.

Simanjuntak,DF., Sari, Dahlia.(2014). Peran Penghindaran Pajak Dalam Mengurangi Biaya Utang Dengan Efektifitas Komite Audit Sebagai Variabel Pemoderasi. SNA 17 Mataram, Lombok Universitas Mataram

Sofyaningsih, Sri., dan Hardiningsih, Pancawati. (2011). Struktur Kepemilikan, Kebijakan Dividen, Kebijakan Utang dan Nilai Perusahaan. Dinamika Keuangan dan Perbankan. ISSN:1979-4878.

Wahidahwati, (2001). Pengaruh Kepemilikan Manajerial dan Kepemilikan Institusional pada Kebijakan Hutang Perusahaab: Sebuah perspektif Theory Agency. Jurnal Riset Akuntansi Indonesia. Vol.5 No. 1.

Winarno, Wing Wahyu. (2015). Analisis Ekonometrika dan Statistika dengan Eviews. Yogyakarta: UPP STIM YKPN.

Yunita, Nancy (2012). Pengaruh Corporate Governance terhadap Voluntary Disclosure dan Biaya Hutang. Jurnal Ilmiah Mahasiswa Akuntansi. Vol 1, No 1.

Yuspitara, A., \& Susena, K. C. (2017). Analisis Pengaruh Penagihan Pajak dengan Surat Paksa terhadap Penerimaan Pajak di Kantor Pelayanan Pajak Pratama Argamakmur Provinsi Bengkulu. Ekombis Review, 5(2). 